\title{
MENUJu GeREJA TERJARING (NETWORKED CHURCH)
}

\section{Kata-kata Kunci: \\ individualisme \\ terjaring \\ Gereja terjaring \\ relasionalitas, \\ Trinitas, \\ kisah iman, \\ komunitas, \\ Gereja, \\ eklesiologi.}

\author{
Gerardus Hadian Panamokta a,b,1 \\ a SMA Kolese Gonzaga, Jakarta Indonesia \\ b Seminari Menengah Wacana Bhakti, Jakarta, Indonesia \\ ${ }^{1}$ oktagerard@jesuits.net
}

Kini kita di Indonesia hidup dalam zaman modern, bahkan sebagian sudah pascamodern. Ciri khas orang modern dan pascamodern ini ... ialah kembali ke dalam kebudayaan nomad, nomad modern. Mobilitasnya tinggi, terlepas dari ikatan-ikatan teritorial yang tetap dan aman. Nomad terutama dalam artian fungsional (pekerjaan, tugas, mata pencaharian), yang membuatnya menjadi perantau, namun juga dalam artian psikologis (tercabut dari akar kultural tradisional, terlempar dalam budaya yang belum jelas).

Realistis, dulu, sekarang, dan di hari depan, kita tetap akan bersituasi diaspora.

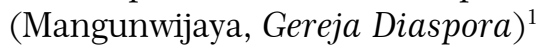

\section{PENDAHULUAN}

Di era digital ini, masyarakat dan dunia kini berada dalam suatu sistem. Layaknya sistem operasi yang bekerja di dalam komputer, masyarakat juga memiliki sistem operasinya sendiri yakni sistem operasi sosial individualisme terjaring atau networked individualism social operating system. ${ }^{2}$ Indivi-dualisme terjaring ialah suatu cara berelasi antar pribadi di dalam masyarakat di mana pola-pola relasi tersebut sudah sedemikian dipengaruhi oleh tiga revolusi yakni revolusi jejaring sosial, internet, dan telekomunikasi bergerak. Jejaring sosial mengubah pola relasi yang sebelumnya cenderung melekat pada kesamaan tempat tinggal atau geografis menjadi relasi itu sendiri yang menghubung-kan antar pribadi sesuai dengan minatnya. Internet menghadirkan perubahan pola interaksi yang selama ini terpaku pada ruang dan waktu menjadi interaksi yang dimedia-sikan dengan komputer. Perantaraan komputer dan internet melampaui batasan ruang dan waktu. Telekomunikasi bergerak semakin menegaskan pola interaksi yang sedemikian personal karena teknologi internet dan komputer cerdas kini masuk ke dalam saku masingmasing pribadi. Individu-alisme terjaring menggagas suatu bentuk berkomunitas yang khas. Teologi dan terlebih eklesiologi ditan- 
tang untuk memaknai secara baru pola relasi interaksi umat beriman di dalam sistem operasi sosial seperti di atas.

Tulisan ini hendak menyajikan kepada sidang pembaca suatu gagasan mengenai Gereja Terjaring atau Networked Church. Isti-lah tersebut hendak memberikan suatu kebaruan dari bentuk pola berkomunitas yang kini sudah sedemikian dipengaruhi oleh sistem operasi sosial individualisme terjaring. Penulis mencoba mengeksplorasi berbagai sumber-sumber pustaka teologi mengenai komunitas umat beriman yang akrab disebut dengan Gereja. Tegangan Gereja yang bercorak institusional dan komunal sedikit diulas. Fokus penulis ada pada komunio. Pertanyaan-nya ialah, sejauh mana komunio dalam Gereja mendapatkan pengaruhnya dari individualisme terjaring. Dalam beberapa kajian dan penelitian, komunitas umat beriman kini semakin memadupadankan pola interaksi daring (dalam jaringan) dan luring (luar jaringan) secara ulang-alik dan juga simultan. Bahkan dipahami bahwa komunitas umat beriman daring menambahkan hal-hal yang kurang dari komunitas umat beriman luring. Maka, gagasan komunio menjadi titik pusat penggalian refleksi teologis penulis dalam artikel ini. Harapannya penulis dapat menawarkan Gereja Terjaring sebagai istilah yang merangkum suasana komunitas umat beriman di era teknologi digital ini. Eklesiologi zaman now.

\section{KOMUNIO DALAM KATOLISISME}

Menurut Richard McBrien, Katolisisme menunjuk tiga prinsip unik yang membedakannya dari tradisi Kristiani lainnya. ${ }^{3}$ Katolisisme sendiri bermakna tradisi Kristiani Katolik, cara hidup, dan suatu komunitas. Salah satunya ialah komunio yang dipahami sebagai "kesatuan seluruh manusia" ${ }^{4}$ Artinya, komunio merupakan persekutuan dan usaha menggapai persekutuan tersebut.

Secara sederhana prinsip komunio meru-pakan kesatuan segenap umat manusia. Kesatuan tersebut punya makna komunal. ${ }^{5}$ Cara manusia menuju Allah dan Allah menuju manusia tidak hanya dalam bentuk mediasi melainkan juga secara komunal. Walaupun perjumpaan ilahiinsani amatlah personal dan individual, perjumpaan tersebut juga punya ruang komunal. Perjumpaan Allah dan manu-sia juga dimungkinkan melalui mediasi komunitas umat beriman. Bagi katolisisme, tidak ada relasi dengan Allah betapa pun intens dan intimnya dengan membuang unsur komunal dari setiap relasi dengan Allah.

Prinsip komunio secara tegas menunjuk Gereja yang adalah komunitas umat beriman. Tiap-tiap manusia beriman berkumpul untuk saling menjadi sakramen dan mediasi bagi Allah yang berkarya secara berkelanjutan demi keselamatan umat manusia. Gereja di sini tidak hanya dipahami secara sosiologis. Di dalam Gereja terdapat pula unsur misteri karena yang ilahi memediasikan diri-Nya. Misteri Gereja selalu memiliki tempat yang penting di dalam teologi, doktrin, praktik pastoral, visi moral, dan kehidupan devosi-onal. ${ }^{6}$ Katolisisme selalu memberi tempat bagi Gereja sebagai sakramen Kristus yang memediasikan rahmat keselamatan melalui sakramen-sakramen, pelayanan, dan elemen institusional lainnya, sekaligus juga sebagai Persekutuan Orang Kudus (communion of saints) dan Umat Allah (People of God). Prinsip komunio menegaskan bahwa iman Kristiani berciri relasional dan komunal. Prinsip komunio ini paling tampak di dalam Gereja di mana berkumpul murid-murid yang beriman pada Allah sehingga memperoleh gambaran awal mengenai Kerajaan Allah. Dalam definisi Gereja, Richard McBrien menjabarkannya demikian:

"Gereja merupakan sakramen dari kehadiran Allah yang Maha Kuasa di antara manusia; Gereja merupakan mediator tindakan penyelamatan Allah bagi manusia; dan Gereja ialah rahmat komunio di mana seluruh manusia dipanggil menuju kepenuhan Kerajaan Allah."”

Dari kutipan tersebut, McBrien menyatakan dengan jelas ketiga prinsip Katolisisme terkandung di dalam Gereja. Maka, gagasan komunio tak dapat dilepaskan dari Gereja, komunitas umat beriman, dan dua prinsip katolisisme lainnya yakni sakramentalitas 
dan mediasi. Di dalam kultur tradisi Nusantara khususnya Jawa, istilah komunio lebih tepat dipadankan dengan paguyuban atau perkumpulan yang terkandung sifat kekeluargaan, di mana terdapat persatuan dan kerukunan di antara para anggotanya. Paguyuban ini berbeda dengan patembayan atau asosiasi yang lebih mengedepankan aspek fungsional dalam relasi antar anggotanya. Bagian ini sudah memberi penegasan akan pentingnya komunio di dalam Gereja terlebih di dalam Katolisisme sehingga makna Gereja yang berkomunio itu makin jelas. Selanjutnya hendak dibahas mengenai makna komunio dalam teks-teks Perjanjian Baru.

\section{PERSEKUTUAN KARENA PARTISIPASI}

Dalam Surat-surat Paulus, Tom Jacobs menangkap bahwa komunio merupakan persekutuan karena partisipasi. ${ }^{8}$ Bentuk partisipasinya ialah 'menyumbangkan sesuatu' dan atau 'mengambil bagian'. Terdapat tiga bentuk partisipasi yakni persekutuan dengan Kristus, persekutuan dengan Roh Kudus, dan persekutuan dalam jemaat.

Partisipasi dalam segala anugerah Kristus memuncak dalam partisipasi dalam diri Kristus sendiri (Bdk. 1 Kor 1:9). Tujuannya ialah kesatuan hidup dengan Kristus walau tidak dijelaskan lebih lanjut mengenai pelaksanaan kesatuan tersebut. Artinya, kesatuan itu memerlukan wujud yang lahir. Dalam terang ini, perjumpaan fisik, tatap muka langsung menjadi hal yang penting. Berkumpul bersama di suatu tempat dan waktu tertentu memang diperlukan agar persekutuan dengan Kristus itu mewujud dalam rupa tak hanya dalam sabda atau kata. Persis di sini tantangan komunitas di dalamjaringan terletak. Puncak persekutuan tersebut ter-maktub dalam ekaristi (Bdk. 1 Kor 10:16.18. 20). Ekaristi berarti koinonia dengan tubuh dan darah Kristus. Zizioulas mengatakan, “... Ekaristi memiliki peran khas dalam mempersekutukan di dalam pengalaman yang khas karya Kristus dan Roh Kudus."

Akhir surat kedua Paulus kepada umat di Korintus ini hendak menunjukkan bahwa koinonia merupakan pemberian Roh Kudus atau "persekutuan yang dikerjakan oleh Roh Kudus", sama seperti kasih-karunia dan cinta-kasih (2 Kor 13:13). Roh Kudus di sini lebih dipahami sebagai pengalaman rahmat sehing-ga kasih-karunia Kristus, cinta-kasih Allah dan koinonia Roh Kudus terungkap. Dalam teks Flp 2:1, kesatuan umat selalu merupakan hasil karya Roh, bukan hanya suatu "persekutuan rohani" dalam arti "kecocokan".

Koinonia mengungkapkan suatu partisipasi bersama, mengambil bagian dalam obyek yang sama seperti kebersamaan dalam iman (Flm 6), pewartaan (Flp 1:5, 2 Kor 8:23, dan 1Kor 9:23), karya (Flm 17 dan Gal 2:9), pende-ritaan (2Kor 1:7 dan Fil 4:14)), dan barang material (Flp 4:15, Gal 6:6, Rm 15:26-27). Partisipasi di sini bernilai konkret sekaligus sakramental. Ia sakramental karena partisipasi berarti tiap anggota ambil bagian dan menyumbang sesuatu dalam perayaan liturgi purba saat itu yakni ekaristi. Partisipasi itu konkret dalam rupa interaksi, pembagian tugas, dan kepemimpinan di dalam jemaat. Maka, komunio mensyaratkan partisipasi konkret dan sakramental.

Gereja yang adalah komunio tak semata perkumpulan, namun juga persekutuan yang berbagi peran dan hidup. Tak hanya yang manusiawi berpartisipasi, yang ilahi pun diyakini terlibat di dalam komunio itu karena Kristus dan juga Roh Kudus turut serta hadir dan memberi sumbangan bagi komunitas umat beriman. Ada perjumpaan di dalam komunitas umat beriman. Tak hanya saling menghadirkan diri, tiap pribadi di dalamnya ikut serta berpartisipasi dalam membangun Gereja. Rupanya terdapat asumsi relasionalitas dalam komunio. Bahkan Schleiermacher dan Möhler memiliki kesepahaman mengenai persahabatan ${ }^{10}$ atau komunio dengan Allah melalui Yesus dan Roh Kudus itu dibagikan pula di antara umat Kristiani di dalam Gereja. ${ }^{11}$ Aspek relasionalitas perlu dibahas kemudian.

\section{Gereja: Jaringan Kelindan Relasi}

Unsur relasional Gereja terungkap lewat ekspresi Doyle yang menyebut Gereja sebagai suatu jaringan kelindan relasi atau the church is a web of interwoven relation- 
ship. ${ }^{12}$ Gereja memang pada dasarnya ialah relasi-relasi yang paling sederhananya ialah relasi antar pribadi umat beriman. Relasi yang paling kompleks ialah relasi Gereja universal dengan Gereja lokal. Jaringan kelindan relasi yang disebut Gereja tersebut merupakan suatu Tubuh Mistik Kristus. Simpul utama dari relasi tersebut tak lain ialah Kristus yang juga sebagai kepala dari tubuh mistik. Artinya, anggota-anggota Gereja menjadi satu tubuh dengan Kristus sebagai kepala. Kesatuan tersebut terjalin karena ikatan relasional. Walaupun demikian, Gereja tetap memerlukan unsur institusional. Hierarki di dalam Gereja pun tetap relevan dan dibutuhkan. Bahkan unsur yuridis sungguh membantu para anggotanya agar dapat menerapkan secara praktis iman dan moralitas Kristiani. Dengan eklesiologi komunio, makna Gereja sebagai komunio sungguh berangkat dari jaringan kelindan relasi. Gambaran dan penjelasan teologis demikian dekat dengan logika teknis dan sosiologis dari sistem operasi sosial terjaring.

Henri de Lubac menjadi salah satu tokoh yang memberi kontribusi besar bagi muncul dan berkembangnya Eklesiologi komunio. Bahkan Doyle membahas eklesiologi de Lubac sebagai akar dari eklesiologi komunio (roots of communion ecclesiology). ${ }^{13}$ Terdapat dua akar utama yang menurut hemat penulis penting untuk disampaikan di sini terkait dengan konteks networked social operating system, yakni unsur paradoks dan misteri dari Gereja serta dimensi relasional.

\section{Paradoks dan Misteri}

Gereja bersifat paradoks dan misteri. Gereja merupakan misteri lantaran Gereja sama sekali sulit dijangkau maknanya oleh pemahaman manusia. ${ }^{14}$ Namun, Gereja juga sekaligus sebagai entitas yang dapat ditemui, dijumpai, dan dirasakan oleh manusia. Di sinilah letak paradoks ${ }^{15}$ atau pernyataan yang seolah-olah bertentangan tetapi mengandung kebenaran. Dennis Doyle membaca Henri de Lubac demikian,

"Kita [manusia] dapat berpartisipasi di dalam misteri, tetapi kedalamannya melam-paui pemahaman kita. Kita dapat menga-lami suatu misteri secara intim, tetapi pemahaman akhirnya melampaui daya budi kita. Suatu paradoks merupakan arahan ke misteri dan juga duniawi. Suatu paradoks merupakan hasil dari koeksistensi di dalam hubungan tegangan dari dua atau lebih hal yang muncul dan saling berkontradiksi atau berlawanan." 16

Kontradiksi ini justru saling melengkapi. Selain itu, hal yang patut dicermati dari unsur tegangan dan paradoks ialah unsur relasi. Relasi menjadi penting sehingga saling mendukung, mengisi, tapi tanpa meniadakan. Tegangan ulang-alik antara dalamjaringan dan luar-jaringan, digital dan analog, serta real dan virtual pun menunjukkan paradoks mutakhir di dalam Gereja. Dalamjaringan dan luar-jaringan pun menuntut relasi.

Ilahi, mistik, sakramental, historis, dan sosial menjadi sifat dimensi relasional dari Gereja. ${ }^{17}$ Tanpa relasi, Gereja tidak terbentuk, tidak bersekutu, tidak berkomunio. Kelima aspek ini kemudian dikembangkan oleh Dennis Doyle menjadi visi dan versi dari eklesiologi komunio ${ }^{18}$ yang juga menunjukkan Gereja itu multi-dimensional. Gereja tidak dapat digagas secara tunggal. Bila de Lubac menegaskan kelima sifat tersebut, Dennis Doyle membawa kelimanya menjadi visi dan versi eklesiologi komunio. Ketegasan bahwa beragamnya gambaran dan pemahaman Gereja semakin diperkaya. Sebelumnya, Avery Dulles menjabarkan Gereja dengan enam model Gereja yaitu institusi, komunio mistik, sakramen, pewartaan, pelayan, dan komu-nitas murid. ${ }^{19}$ Persekutuan Gereja tetap memberi ruang pada tegangan atau paradoks karena tanpanya relasi menjadi tidak relevan. Relasionalitas melandasi gagasan Gereja sebagai komunio atau persekutuan.

\section{RELASIONALITAS: ASUMSI DASAR UTAMA}

Asumsi dasar relasionalitas dari gagasan Gereja sebagai komunio berkaitan dengan gagasan networked individualism. Di dalam Kristianitas, relasionalitas ini mengakar di dalam Trinitas atau Allah Tritunggal. Allah yang tiga pribadi tersebut saling berelasi sehingga manusia meneladan aspek relasio- 
nalitas dari Allah. Aspek relasionalitas pun terkandung di dalam antropologi Kristiani.

\section{Meneladan Pribadi Allah Tritunggal}

Allah yang trinitaris mengandaikan relasi. Allah yang monistik tidak demikian. Konsep Allah Tritunggal berangkat dari konsep Soteriologi atau teologi penyelamatan. Karya keselamatan yang dilakukan Yesus Kristus di dalam dunia hanya menjadi masuk akal (Kristologi) di dalam lingkup karya keselamatan (Soteriologi) yang dirancang oleh Allah Tri-tunggal (Trinitas). Hubungan antara Yesus Kristus, Sang Putra Allah dengan Allah Bapa menjadi jelas dengan Allah Tritunggal. Dalam tradisi Katolisisme, Allah berkenan menyela-matkan manusia di dalam sejarah. Keselamatan itu terlahir lewat kehendak Allah yang terus menerus berelasi dengan manusia yang kerap tidak setia, padahal manusia diciptakan menurut "gambar dan rupa Kita" (Kej 1:26).

Trinitas selalu terkait dengan dua hal. Hal yang pertama mengenai identitas sekaligus relasi dari Allah Tritunggal itu sendiri. Artinya, Allah tidak hanya Tritunggal terkait dengan manusia melainkan juga sungguhsungguh Tritunggal suci. Kedua, berkenaan dengan karya atau misi dari ketiga pribadi ilahi. Poin yang kedua ini hendak menunjukkan bahwa Allah selalu berupaya untuk dekat dan menyelamatkan manusia di dalam karya kesela-matan. Karl Rahner menyebut yang pertama sebagai the immanent Trinity dan yang kedua sebagai the economic Trinity. ${ }^{20}$ Imanen dan ekonomi menunjukkan betapa jauh dan dekatnya Allah Tritunggal bagi manusia; Allah yang berkodrat relasional.

Untuk dapat memahami kodrat relasional Allah Tritunggal, cara berpikir yang lebih melihat the ultimate Being atau the unmoved mover sebagai suatu substansi atau Being atau kodrat perlu diubah menjadi cara berpikir yang melihatnya sebagai pribadi atau pro-sophon atau persona. Pendekatan untuk mengubah cara pandang ini bersifat ontologis dari yang monistik, individualis, dan terisolasi menuju pada ontologi yang komunal, relasio-nal, dan bebas. ${ }^{21}$ Zizioulas berpendapat,
"Hakekat Allah itu hakekat yang relasional: tanpa konsep komunio akan sulit bicara mengenai hakekat Allah. ... Sulit bicara mengenai 'Keesaan Allah' tanpa bicara sebelumnya mengenai Allah yang adalah 'komunio', yakni Tritunggal Maha Kudus. Trinitas merupakan konsep ontologis primordial dan bukanlah suatu ide yang ditambahkan ke dalam kodrat ilahi... Kodrat Allah sebagai 'Allah' tidak memiliki isi ontologis, tak berhakikat sejati bila tanpa komunio."22

Identifikasi hipostasis dan persona dalam Trinitas memungkinkan hakikat dari aspek relasionalitas. Dennis Doyle mengungkapkan bahwa relational being sebagai inti dari segala kenyataan dan eksistensinya $^{23}$ mendapat pertanggungjawaban ontologis. Segala sesuatu itu personal. Allah Kristiani merupakan suatu komunitas relasional.

Gagasan Allah Tritunggal sebagai komunitas relasional dapat ditemukan dari pemikiran Para Bapa Gereja pastoral seperti Ignasius, Ireneus, dan Atanasius. Ketiganya menyampaikan bahwa dalam menggereja, terlebih pengalaman berkumpul yang ekaristis menjadi landasan untuk memahami kehidupan orang Kristen dan komunio. Allah memberi teladan relasi bagi manusia. Antropologi manusia itu relasional.

\section{Antropologi Manusia Kristiani}

Antropologi Kristiani pun pada hakikatnya relasional karena manusia ialah imago Dei. Maka, berkomunio atau berada di dalam komunitas merupakan suatu hal yang asasi bagi manusia Kristiani. ${ }^{24}$ Antropologi pneumatologis (pneumatological anthropology) dari Yves Congar dan Elizabeth Groppe ${ }^{25}$, yang berakar dari Kej 26:1. Artinya, manusia dicip-takan menjadi sosok atau pribadi yang terarah pada pribadi yang lain dan dipanggil ke dalam komunio. Groppe mengartikulasikan demikian,

“... Pribadi-pribadi ilahi mengada dengan, melalui, dan bagi satu dengan yang lainnya. Manusia diciptakan di dalam imago Dei yang cara mengadanya ialah "beingtoward” (être-á) atau 'ada yang menuju' pada satu dengan yang lain dan menemukan kepenuhannya hanya di dalam 
komunio. Manusia diciptakan untuk melampaui dirinya di dalam pemahaman dan cinta pada sesama; yang secara paling fundamental, manusia memiliki suatu kemampuan alami untuk dapat dipanggil oleh Allah." 26

Dengan demikian, dapat dikatakan bahwa antropologi pneumatologis memiliki warna relasional. Bahkan kebebasan yang dimiliki manusia pun sesungguhnya berciri relasional. Groppe dengan piawai berujar, "kebebasan manusia bukanlah sesederhana kebebasan memilih secara individual melainkan sesung-guhnya kebebasan untuk menggapai suatu relasi tepat yang saling menguntungkan dan berkomunio, relasi yang secara aktif mengundang yang lain dan aktif untuk menerima Allah." 27 Antropologi itu pneumatologis lan-taran Roh Kudus menyempurnakan kebebasan itu sehingga relasi tepat itu sungguh mengarah pada Allah. Maka, aspek relasional dan komunal memang tertanam secara mendalam di jantung insani manusia.

Thomas Sheehan mengemukakan relasionalitas dalam memahami proyek transendental Karl Rahner. ${ }^{28}$ Manusia selalu mengada dalam bentuk relatedness artinya ia selalu terikat dan terhubung dengan apa dan siapa pun. Keterhubungan-dengan-yanglain (rela-tedness-to-another) itu sama dengan keterhu-bungan-dengan-dirinya-sendiri (relatedness-to-oneself). Manusia tidak dapat tidak berhubungan dengan orang lain atau pun dunia ciptaan lainnya.

Sheehan mendefinisikan manusia sebagai self-related otheredness atau diri-yangterhubung-dengan-yang-lain lantaran relasi dengan yang lainlah yang memungkinkannya berelasi dengan dirinya sendiri. ${ }^{29}$ Diriyang-terhubung (self-relatedness) berarti diri-yang-sadar (self-relatedness) dan diriyang-bertanggungjawab (self-responsibility). Dengan demikian, manusia menunjukkan dirinya memiliki roh atau spirit. Otheredness menunjuk bahwa manusia memiliki kebu-tuhan dipengaruhi oleh yang lain tetapi terbatas dalam arti hanya pada suatu bentuk duniawi dari yang lain itu.

Sheehan mengupayakan pembahasaan self-related otheredness itu dengan istilah
Rahner Geist in Welt atau roh di dunia yakni bahwa pada dunia material ini roh mampu melampaui atau mengada bahkan tanpa sesuatu dari dunia material ini. ${ }^{30}$ Maka, proyek transendental Rahner bagi Sheehan merupakan suatu tolehan (turn) yang lebih dari sekadar 'kembali kepada subyek'. Justru lebih tepat 'kembali kepada subyek-didalam-relasi' (a turn to the subject-in-relation). ${ }^{31}$ Aspek relasionalitas manusia makin terungkap dari proyek tolehan transendental dari Rahner menurut Sheehan.

Roberto Goizueta dengan antropologi Kristiani Amerika Latin mengungkapkan 'komunitas berperan sebagai rahim lahirnya diri (self)'.$^{32}$ Pribadi itu secara intrinsik relasional. Manusia saling terhubung dengan yang lain baik itu jagad besar maupun jagad kecil. Dengan alam semesta, manusia terhubung. Dengan sesama manusia, ia pun terhubung. Goizueta menulis demikian,

"Identitasku diberikan oleh orang tuaku, saudara-saudariku, sahabat-sahabatku, dan relasiku dengan yang lain dan komunitas-komunitas di mana aku terkait; tiadalah itu 'aku' tanpa yang lain itu. Aku ialah sesuatu yang partikular, konkret, dan kekhasan yang menubuh dari sekian banyak relasi; bila seseorang berjumpa dengan diriku, mereka berjumpa pula dengan orang tuaku, dengan saudarasaudariku, dengan saha-bat-sahabatku, komunitasku, orang-orang yang ku kenal, juga Allah yang menciptaku dan alam semesta yang menumbuhkem-bangkan diriku." 33

Relasi sungguh menjadi sesuatu yang hakiki dan tidak dapat dilepaskan. Konteks masyarakat Amerika Latin di mana Goizueta hidupi dan teliti aspek komunal dan relasionalnya sungguh amat mengemuka. Konteks masyarakat Indonesia pun pada dasarnya memiliki akar relasionalitas dan komunal yang kuat. Driyarkara dalam upayanya mencari sosialitas dalam alam Indonesia mengungkapkan bahwa

"Dengan hubungan ini dapat dikatakan bahwa seluruh Pancasila berupa pengakuan sosialitas manusia. "Jikalau saya peras, yang lima menjadi tiga, yang tiga menjadi satu, maka saya mendapat satu 
perkataan Indonesia yang tulen, yaitu perkataan 'gotong royong'”. ... Maka dari itu, jika dikatakan bahwa gotong royong itu merupakan perasaan dari Pancasila, maka hal itu juga berarti bahwa gotong royong berupa dasar, berupa sesuatu yang asasi. Apakah yang termuat dalam ide itu? Kerja sama, karena hidup bersama. Jadi, sosialitas." 34

Driyarkara mengungkapkan aspek relasionalitas dan komunal khas Indonesia melalui Pancasila. Komunio atau persekutuan juga mengakar dalam antropologi manusia Indonesia.

\section{MISTERI DAN ROH KUDUS: GEREJA YANG TERUS MEREFORMASI}

Untuk dapat menangkap aspek relasionalitas di dalam Gereja, pendekatan eklesiologi yang komunio perlu dikedepankan. Dibandingkan dengan eklesiologi manual atau monarki, eklesiologi komunio merayakan aspek relasionalitas.

\section{Gereja berdialektika dengan dunia ${ }^{35}$}

Dalam konteks struktur Gereja, struktur itu mesti dipahami dalam situasi dan kondisi yang sesuai dengan masa kini. Sisi misteri tetap dijaga dengan memberi tempat pada perkembangan sejarah. Perlu sikap hati-hati dalam menanggapi struktur Gereja pasca Konsili Vatikan I dengan ajaran infalibilitas. Dialektika antara Gereja sebagai misteri dan sebagai kenyataan historis dapat diterapkan di sini dengan tidak jatuh pada sikap "creeping infallibility". Artinya, sikap yang melulu menempatkan ajaran magisterium Gereja yang biasa sebagai sesuatu yang tidak dapat salah. Makna infalibilitas pun bergeser. Dampaknya ialah studi mengenai Gereja pun menjadi sempit. Doyle menyebutnya sebagai hierarkologi atau kajian mengenai hierarki atau kaum tertahbis saja ${ }^{36}$. Padahal cakupan studi mengenai Gereja jauh lebih besar daripada klerus atau hierarki.

\section{Peran Roh Kudus}

Congar punya gagasan bahwa peran Roh Kudus berbeda dengan Kristus di dalam Gereja. ${ }^{37}$ Bila Kristus ialah pembentuk atau peletak dasar Gereja, Roh Kudus mendam- pingi Gereja terus menerus bahkan setelah Gereja terbentuk. Roh Kudus senantiasa punya andil agar Gereja terus menerus memperbaharui dirinya di tengah situasi dan kondisi jaman. Pneumatologi bagi Congar lebih dari sekadar teologi dogmatis mengenai Pribadi Ilahi Ketiga melainkan mengenai dampak dari visi kontekstualisasi Gereja di mana Roh Kudus berkontribusi melalui karisma dan kehendaknya dalam menyeleng-garakan Gereja. ${ }^{38}$ Gereja pun memiliki sisi eskatologis, proyek yang belum usai.

Congar menggunakan bahasa penyebab Aristotelian $^{39}$ dalam menjelaskan peran Roh Kudus dan hierarki di dalam Gereja. ${ }^{40}$ Congar menyebut hierarki sebagai tubuh apostolik (uskup, imam, dan diakon). Tubuh apostolik dan Roh Kudus sama-sama berperan sebagai penyebab efisien dan formal dari Gereja, membentuk Gereja. Tubuh apostolik merupa-kan penyebab formal yang tinggal di dalam sekaligus menyusun Gereja sedangkan Roh kudus merupakan penyebab kuasiformal yang tinggal di dalam tetapi tidak menyusun Gereja.

Dengan skema Roh Kudus dan tubuh apostolik sebagai penyebab efisien dan formal, Congar melampaui eklesiologi manual yang menempatkan Gereja sebagai tak lekang waktu dan tak butuh pembaharuan (timeless and irreformable). Congar menyebutnya sebagai eklesiologi pneumatologis (pneuma-tological ecclesiology), "eklesiologi yang menekankan bahwa Roh Kudus bersama dengan Yesus Kristus co-institutes atau bersama-sama menginstitusi Gereja, memberdayakan sakramen-sakramen dan doksologi Gereja, membangun Gereja dengan karisma, dan membuat Gereja itu satu, kudus, Katolik, dan apostolik." ${ }^{41}$ Dengan eklesiologi pneuma-tologis ini, eklesiologi terjaring atau net-worked ecclesiology pun mendapat dukungan karena Roh Kudus dapat berkarya di situ.

Doyle mengapresiasi Congar dengan menyebutnya sebagai "eklesiolog langka yang memahami Gereja dengan menekankan pentingnya perubahan struktur dan menggali inspirasi spiritualitas" 42 . Dengan komunio, Congar menekankan bahwa kolegialitas 
dan suasana konsilier di dalam Gereja itu penting dan penerimaan atau reception merupakan suatu proses aktif tiap anggota Gereja sebagai pribadi-pribadi di dalam komunio melalui peran Allah Roh Kudus. ${ }^{43}$ Dari Congar, Gereja selalu berada di dalam sejarah, di dalam proses menjadi yang berdialektika dengan dunia. Di situlah peran Roh Kudus turut mempengaruhi warna dan bentuk komunio dari Gereja yang njamani, Gereja Terjaring.

\section{Narasi Iman sebagai patokan Gereja yang reformatif}

Bagi Congar, Gereja yang sekaligus komunio dan institusional itu membutuhkan reformasi:

\begin{abstract}
“... setiap gerakan aktif di dalam Gereja merepresentasikan suatu gerakan yang mengatasi apa yang sudah ada sebelumnya dan mengambil daya dari bentuk baru ke dalam sumber-sumber sekaligus energi hidup menggereja. Dengan cara demikian, setiap gerakan aktif memiliki kualitas refor-masi tertentu. Hal ini sungguh benar pada era kontemporer seperti pada jaman lainnya, bahkan terlebih masa kini." ${ }^{44}$
\end{abstract}

Gereja perlu mereformasi dirinya terlebih dalam sistem operasi sosial individualisme terjaring. Reformasi di sini berbeda maknanya dengan revolusi ${ }^{45}$ yang memang kerap meng-hadirkan sesuatu yang tidak (ny)aman. Gereja itu berada dalam tegangan yakni membawa dan meneruskan tradisi sekaligus dibangun dan dibentuk terus menerus. Dalam konteks individualisme terjaring, gagasan Congar mengenai reformasi Gereja dapat diterapkan dengan berfokus pada narasi iman.

Kisah iman berasal dari pengalaman hidup umat beriman dalam menanggapi undangan Allah. Sejarah keselamatan Allah bagi manusia direkam oleh nenek moyang umat beriman di dalam suatu narasi yang diteruskan (tradisi). Konkretnya ialah Kitab Suci baik itu Perjanjian Lama dan Perjanjian Baru. ${ }^{46}$ Kitab Suci ter-sebut memuat Sabda Allah yang tak pernah gagal, "Para pemimpin umat baik itu para raja dan imam ialah para pendosa. Hanya Sabda dan iman akan Allah yang tak pernah gagal." ${ }^{47}$ Umat beriman yang mengalami langsung perjumpaan dengan Allah sudah berlalu. Kini jejakjejaknya dapat ditelusuri melalui kisah iman yang tertulis beserta kisah iman yang terus menerus diajarkan, diwartakan, terlebih dihidupi oleh generasi-generasi berikutnya. Setiap menjadi pewarta, menjadi nabi yang profetik lewat narasi kehidupan yang mereka alami. $^{48}$

Komunitas dibentuk oleh karakter berdasarkan tutur kisah pribadi di dalamnya. Komunio itu pun menjadi semakin berkarakter lantaran ada sesuatu yang dibagikan. Kisah iman dari Perjanjian Lama mengajarkan banyak hal tentang komitmen dan kewajiban moral. Dari kisah Nuh, Abraham, Yusuf, Musa, hingga para nabi, raja, dan hakim, gagasan mengenai perjanjian hendak menegaskan bahwa Allah sendiri yang berinisiatif untuk memilih dan membentuk umat-Nya. Mereka tak lain ialah komunitas umat beriman yang pasca Perjanjian Baru disebut sebagai Gereja. Allah yang relasional itu berinisiatif untuk mengikat perjanjian. Komitmen datang pertama-tama dari Allah. Nenek moyang manusia me-nanggapinya. Semua itu terangkum di dalam kisah yang ditradisikan, diteruskan hingga kini. Komitmen dengan demikian dapat lahir dari narasi yang didengungkan, diwariskan, dan dilatih dalam hidup keseharian. Stanley Hauerwas menegaskan hal ini demikian,

"Karakter kita dibentuk oleh banyak peraturan, metafora, dan kisah yang beragam sehingga memberikan suatu rancangan atau kesatuan dari sekian banyak hal yang mesti kita lakukan atau tidak dalam hidup kita. Jika hidup kita hendak reflektif dan koheren makan visi kita mestinya diatur oleh metafora atau narasi dominan. Maka dari itu penting bagi hidup moral kita untuk memberi ruang kepada metafora yang membentuk visi demi menyeimbangkan dan memastikan satu dengan lainnya dalam rangka kesesuaian dengan tuntutan hidup dan keseluruhan 'rencana hidup' yang kita hidupi." 49

Tak hanya komitmen, Allah lebih lanjut menawarkan perjanjian dalam level yang lebih maju. Dalam kisah Abraham (Kej 12) misalnya, Allah menjanjikan keturunan, tanah, dan berkat bagi Abraham asalkan 
Abraham mau mengikuti perintah Allah. Sebaliknya, jangan harap ketiga hal tersebut dipenuhi oleh Allah. Proses narasi tentang perjanjian yang mengikat baik Allah dan umat pilihan-Nya berujung pada kewajiban moral. Artinya, kisah tersebut mengajak pendengarnya untuk mengambil jarak dan menentukan pilihan yakni ikut tawaran Allah atau tidak. Narasi iman yang berakar dari tradisi Kristiani menjadi alasan bahwa komitmen dan kewajiban moral itu tetap lestari, bahkan di dalam komunitas umat beriman Kristiani daring.

Kisah iman tidak hanya mengajak Gereja untuk terus menerus mereformasi dirinya. Narasi iman juga menjadi faktor untuk mengikat komitmen di dalam komunitas umat beriman. Stanley Hauerwas menegaskan bahwa dengan berbagi kisah iman baik itu yang dipahami dan dihayati secara pribadi menjadi proses untuk membentuk komunitas. ${ }^{50}$ Dalam pemikiran Campbell tentang komunitas umat beriman Kristiani daring, narasi iman merupakan faktor krusial nan penting yang menyatakan bahwa pribadi-pribadi yang terjaring itu merupakan sekumpulan pribadi yang disebut Gereja. ${ }^{51}$ Mereka saling mengakui iman yang sama dengan menghidupinya secara khas. Narasi membentuk identitas diri dan iman mereka. Komunitas pun dibentuk berdasarkan narasi iman yang dipelajari dan dipertukarkan terus menerus baik itu dalam perjumpaan fisik atau pun dalam perjumpaan dengan representasi digital. Gagasan Roberto Goizueta bergaung di sini yakni diri itu dibentuk oleh komunitas.

Narasi iman membutuhkan interpretasi dan pemahaman terus menerus. Persis dalam proses interpretasi, pewartaan, dan pemakna-annya misteri ilahi dan terutama Roh Kudus ikut ambil bagian dan kontribusi. Sabda Allah yang dinarasikan oleh manusia dalam Kitab Suci dan Tradisi menjadi salah satu makna dari Gereja menurut Congar, “... Gereja ialah ... gabungan atau pun kesatuan dari prinsip formal ilahi dengan prinsip material manusiawi. Dengan ini hendak dipahami bahwa Gereja merupakan realita insani-ilahi yang lahir dari kesatuan tersebut." 52

\section{SESAMAKU MANUSIA: SIAPA DAN DI MANA?}

Pertanyaan mengenai siapa sesamaku, di mana, dan bagaimana berelasi dengannya menjadi perhatian utama terkait dengan persinggungan antara sistem operasi sosial terjaring (networked) dengan teologi. ${ }^{53}$ Pertanyaan ini menjadi relevan karena kini komunio Gereja semakin dituntut untuk sedemikian personal. Komunio bukan saja menjadi tradisi atau penerusan suatu bentuk berpaguyuban yang semena-mena atau dipak-sakan. Bila pun sebelum teknologi digital merambah hidup manusia, tiap-tiap pribadi dapat pula memilih untuk bergabung atau tidak. Bahkan bisa si pribadi itu memutuskan untuk bergabung, ia tetap bisa menjadi anggota yang aktif atau pun pasif seperti silent reader. Namun teknologi digital memberi suatu kemungkinan baru yang lebih dari pilihan menidak dari berkomunio yang fisik dan lokal. Kini networked individuals itu semakin menggunakan kebebasannya untuk memilih kepada siapa mereka berkomunio baik itu di dalam mau pun di luar jaringan. Bagi networked individuals siapa sesamaku dan di mana sesamaku berada mesti dijawab.

\section{Siapa Sesamaku Manusia?}

Secara spesifik masalahnya terletak pada hadirnya lingkungan baru dalam bentuk representasi digital. Refleksi dan pemahaman relasionalitas dan komunio lebih banyak berangkat dari lingkungan fisik. Kini makna lingkungan dan aspek geografis mereggang hingga memporikan batas-batas ruang dan bahkan waktu. Dunia digital dan virtual menambah dunia fisik, dunia di mana Allah sendiri berinkarnasi. Allah Putra mendarah dan mendaging menjadi manusia di dalam dunia fisik. Komunitas atau pun paguyuban pun selama ini terkait dengan fisik. Aku hadir bersama dengan yang lain di dalam komunitas lantaran tubuhku hadir dekat dengan tubuh yang lain. Maka pertanyaan siapakah sesa-maku manusia di sini dapat dikembangkan menjadi demikian,

"apakah kehadiran yang mendarah-daging yang tampak dari inkarnasi Allah dalam diri Yesus dari Nazaret dan komunitas 
gerejawi merupakan suatu komunitas Kristiani sejati yang tidak lagi dapat dinegosiasikan? Apakah gagasan mengenai Gereja hanya terbatas pada suatu representasi fisik penuh di dalam situasi waktu dan ruang tertentu? Dapatkah seseorang sungguh menjadi manusiawi di lingkungan dalam-jaringan, dan bagaimana seseorang tersebut mewujudkan kasih di lingkungan ter-sebut?"54

Kesulitan menjawab pertanyaan tersebut ada pada tiga poin. Pertama, manusia diciptakan dalam bentuk tubuh fisik. Menolak sisi fisik dan material dari tubuh manusia demi dunia yang spiritual atau pun virtual, seperti gnostisisme, ditolak. Kedua, manusia diciptakan sebagai makhluk sosial. Ketiga dan paling penting ialah, Allah sendiri menubuh dengan mendarah-daging dalam diri Yesus sehingga pewahyuan Allah menjadi penuh. Selain Allah Putra yang memanusia sehingga menjadi sakramen atau tanda dan sarana penuh kehadiran Allah, banyak hal di dalam Kristianitas menggunakan sarana fisik sebagai sakramen-sakramen. Tiga hal di atas menjadi tantangan dalam melihat secara teologis siapa sesamaku manusia dalam konteks indivi-dualisme terjaring (networked individualism).

Tegangan ulang-alik antara dalam -jaringan dan luar- jaringan dipandang sebagai sesuatu yang manusiawi, yang paradoks. Manusia kerap kali berjumpa dengan dunia dan budaya yang berbeda. Berhadapan dengan situasi keberbedaan tersebut yang menghasilkan rasa tidak (ny)aman, manusia belajar untuk bernegosiasi dengan realitas kultural yang baru. Kreativitas dan inovasi manusia dalam berjumpa dengan situasi tegangan paradoksal ini merupakan kisah sepanjang sejarah. Kini, manusia dihadapkan pada bagaimana mengupayakan agar sistem operasi sosial individualisme terjaring sung-guh menghadirkan interaksi dan relasi yang sejati bagi manusia.

Untuk itu, Campbell dan Garner menyarankan agar teologi yang merefleksikan jaringan (baik itu networked theology atau pun cybertheology) sungguh menyadari bahwa manusia itu unik dan memiliki kemampuan untuk menjadi sesama baik itu di da- lam lingkungan terjaring mau pun tidak. Fokusnya ada pada gagasan bahwa manusia itu gambar dan rupa Allah. Baik dirinya sendiri mau pun orang lain, setiap manusia secitra dengan Allah. Kemanusiaan dan kekomunalan yang manusia miliki bersumber dari Allah tanpa peduli lingkungan dan konteksnya baik itu fisik atau pun digital. ${ }^{55}$ Maka, sesamaku manusia dalam bentuk representasi digital di dalam-jaringan itu tak lain ialah sesamaku yang juga menubuh dan hadir di dalam dunia fisik, luar-jaringan, yang sama-sama segambar dengan Allah Tritunggal yang relasional dan komunal.

\section{Di mana sesamaku manusia?}

Pertanyaan kedua terkait dengan lokalitas sesama manusia yang padanya manusia saling terhubung, terelasi, atau terjaring. ${ }^{56}$ Dengan individualisme terjaring, sulit mengetahui dengan pasti di mana sesamaku berada. Mungkin ia berada di sebelah kamar atau ia tinggal di belahan bumi yang lain. Yang tahu pasti ialah si pribadi itu sendiri. Pertanyaan ini terkait dengan konsep kebertetanggaan (neigborhood) yang kini saling tumpang tindih antara yang fisik dan digital. Ada tiga dimensi terkait dengan konsep kebertetanggaan atau kebersamaan atau komunitas atau paguyuban itu. ${ }^{57}$ Dimensi pertama terkait mengenai pengalaman atau pun eksistensi manusia. Dimensi kedua berhubungan dengan perjumpaan manusia dengan Allah. Dimensi ketiga terkait dengan bagaimana diri yang beriman ini tergabung di dalam komunitas umat beriman (Gereja) yang memiliki misi di dunia. Ketiga dimensi ini dapat menyasar pertanyaan seputar di mana sesamaku manusia.

Konteks kebersamaan dengan sesamaku manusia pada jaman ini terjalin di dalam lingkungan yang paradoksal yakni privasi yang publik (publicized privacy). Inilah dimensi pengalaman manusia. Kondisi demikian berupa seseorang dapat berpartisipasi dalam dunia digital yang publik di mana dalam keterlibatannya itu ia berada dalam situasi dirinya yang amat privat. Ia terkoneksi dengan dunia publik ketika ia berada di kamar tidur bahkan di kamar mandi. Itulah hiperkonektivitas terus menerus. ${ }^{58}$ 
Diskusi mengenai di mana sesamaku berada terkait dengan batasan (boundaries $)^{59}$ antara yang privat dengan yang publik. Batasan itu membuat manusia dapat men-cerap sesamanya yang ada di dalam ruang yang dekat diriku atau yang jauh dengan diriku. Pada siapa aku berbagi dengan hidupku yang utuh intim dan atau dengan siapa aku berperan di hadapan khalayak ramai. Sesamaku manusia juga dipandang dari juga bagaimana tiap pribadi dan yang lain saling melintasi batasan tersebut.

Gambaran biblis terkait konsep kebersamaan, kebertetanggaan, serta berkomunitas terlebih tentang di mana sesamaku manusia tertuang dalam kisah orang Samaria yang baik hati (Luk 10:25-37). Kisah ini menjadi simbol bagaimana perjumpaan antar manusia merupakan sarana berjumpa dengan Allah yang mengarah pada keadilan, belas kasih, dan kerendahan hati di hadapan Allah. Tumpang tindih dan berporinya batasan privat dan publik, fisik dan digital, dalam-jaringan dan luar-jaringan mestinya dilihat dengan intisari kisah Orang Samaria itu. Di mana pun sesamaku berada yang kini mengulak-alik dalam dan luar jaringan, sesamaku itu ialah kepada mereka aku mengarahkan tindakanku untuk bersikap adil, kasih, dan rendah hati. Sikap demikian ini hendaknya menjalin suatu relasi dan bukannya definisi fisik geografis. Dimensi perjumpaan manusia dan Allah terjawab sudah dengan mengundang teologi untuk membuka diri dan berefleksi akan ranah digital yang menambahkan dunia fisik keseharian manusia. ${ }^{60}$ Bila Allah sudi hadir dalam dunia fisik, dunia di luar-jaringan, tentunya ia pun juga sudi hadir di dalam dunia digital, dunia dalam-jaringan yang kini dunia tempat hidup manusia merupakan paduan ulang alik antara keduanya ${ }^{61}$

Dimensi ketiga yang terkait dengan aspek relasional manusia di dalam Gereja dan misinya tidak dapat dipisahkan dari gagasan dimensi pertama dan kedua. Artinya, gagasan bersama dengan sesamaku manusia baik itu bertetangga, berkomunitas, berpaguyuban itu menyangkut aspek komunal dan etis me-ngenai bagaimana umat Allah, pengikut Yesus Kristus menghidupi imannya di dalam dunia keseharian yang semakin ulang-alik itu. ${ }^{62}$ Sebagai umat beriman, manusia dipanggil untuk berkomunio dan menghidupi imannya yang kini berada di dalam dua dunia sekaligus, baik iman yang hidup di luar-jaringan dan iman yang hidup di dalamjaringan. Artinya, aspek-aspek etis dan komunal yang diajarkan oleh Yesus dan Gereja juga berlaku bagi dua ranah baik fisik dan digital. Tantangan ini baru bagi para networked individualism untuk menghidupi imannya yang komunal dan relasional di sistem operasi sosial individualisme terjaring.

Dua pertanyaan di atas baik itu mengenai siapa sesamaku dan di mana sesamaku manusia menjadi tidak hanya tantangan bagi teologi, tapi juga bagi umat beriman yang terus menerus menggulati hidup dalam dunia yang terus berubah. Dengan pertanyaan ini, asumsi dasar relasionalitas dan komunal dari manusia semakin ditegaskan. Tak hanya itu, narasi iman Kristiani juga menemukan relevansinya di sini. Cerita mengenai Orang Samaria yang baik hati masih tetap mengusik hati lewat hadirnya ruang digital. Komitmen sebagai seorang Kristiani yang meneladan Yesus Kristus yang murah hati mengundang untuk berbuat. Bila Sang Guru mengajarkan dan memberi contoh untuk beramal kasih secara konkret, kewajiban moral pengikut-Nya entah itu yang mendengar kisah ini baik secara luring mau pun daring tetap mendesak diri untuk bertindak. Gagasan Gereja sebagai komunio yang pun diteguhkan. Namun, relasionalitas dan komunal dari komunitas umat Gereja mendapat tantangan konkret untuk melihat siapa dan di mana sesamaku manusia.

Komunio Gereja mesti makin adaptif lantaran situasi jaman yang makin cair. ${ }^{63}$ Artinya komunio Gereja di era digital kini bisa jadi tidak solid atau padat yakni jelas dalam arti siapa-siapa saja yang berkumpul dan di mana mereka bertemu. Kini situasi dunia makin cair sehingga komunio Gereja dapat dibentuk oleh pribadi-pribadi yang tidak menjejak pulau dan tanah yang sama. Mereka berelasi dan berkomunio lintas batas-batas netra, bahkan lintas dalam dan luar jaringan. Pejiarahan untuk terus 
melihat sisi dasariah manusia yang selalu terhubung dengan yang lain memang perlu terus menerus diuji. Apalagi kini dunia tidak lagi hanya yang fisik belaka tapi juga sekaligus dengan tumpang tindih dan ulang alik hadir dengan tambahan dari dunia digital.

\section{PERPADUAN GEREJA TERITORIAL DENGAN GEREJA TERJARING}

Romo Mangunwijaya menawarkan suatu strategi yang menarik. Gagasan Gereja Diaspora yang ia ajukan merupakan suatu perpaduan. Gereja Diaspora bukanlah suatu pengganti dari Gereja Teritorial. Artinya Gereja dengan struktur dan organisasi seperti sekarang ini masih tetap dipertahankan. Hanya saja Gereja Teritorial yang hierarkis dan yuridis tersebut perlu dipadupadankan dengan Gereja yang lebih luwes bergerak, berdinamika, dalam situasi yang diasporis. Dalam bahasa kekinian atau dalam kesatuan teks yang penulis bahas ini ialah situasi terjaring (networked). Kiranya baik untuk mencermati gagasan Romo Mangun sehingga dapat diperoleh suatu gagasan dan kesim-pulan praktis yang dapat dibuat dalam konteks hidup menggereja di Indonesia.

Sebelum melangkah lebih jauh, kita perlu memahami dahulu perbedaan situasi masya-rakat yang terjadi di masa Romo Mangun saat ia menggagas Gereja Diaspora dan situasi individualisme terjaring. Pertama, situasi masyarakat Indonesia di era Romo Mangun itu sedang beralih dari masyarakat tradisional agraris menuju masyarakat industri. Masyarakat pasca-industri berlangsung dalam sistem operasi sosial individualisme terjaring. Kedua, manusia di dalam masyarakat industri banyak bergerak dari sisi fisik spasial. Banyak pribadi berpindah tempat. Di individualisme terjaring, pribadi masih berpindah namun perpindahan yang lebih masif terjadi di dalam-jaringan. Representasi digital dan data-data informasi yang diakses oleh pengguna lebih banyak berpindah dibandingkan dengan penggunanya yang cenderung menetap atau berpindah ke tempat sama. Situasi dan konteks yang berbeda menuntut transformasi yakni dari Gereja Diaspora menuju Gereja Terjaring.

Salah satu visi unggul dari gagasan Gereja Diaspora Mangunwijaya ialah jaringan pastoral transteritorial dan suprateritorial. ${ }^{64}$ Kategori-kategori jaringan tersebut ialah:

- Persekutuan-persekutuan pendalaman rohani atau pembekalan rohani demi ketahanan diri / konsolidasi diri atau kesalehan. Persekutuan ini merupakan kelompok yang terkumpul karena kesamaan minat dalam hal spiritual dan rohani. Jaringan persekutuan rohani spiritual ini menemukan peluang untuk mengembangkan pengalaman rohani dengan menambahkan aspek artistik dan kreasi melalui media sosial.

- Perhimpunan-perhimpunan

pendidikan informal atau pendidikan kategorial. Jaringan diaspora ini muncul di dalam institusi pendidikan. Beberapa dari kelompok ini merupakan jaringan kelompok seminat lewat profesinya. Media sosial semakin memberdayakan mereka, terlebih dalam membagikan informasi akan peluang di mana mereka dapat terlibat dan berkontribusi bagi masyarakat. Terlebih bagi para rekan muda-mudi yang masih di dalam jenjang pendidikan dasar, menengah, dan tinggi, ketersediaan internet dan komputer memudahkan mereka untuk berbagi ilmu pengetahuan, pengalaman, dan juga informasi. Mereka kini bekerja dengan asyik sambil mengobrol di dalam ruang-ruang obrol virtual. Justru obrolan mereka kerap merupakan pembahasan mengenai materi mata pelajaran tertentu, tugas-tugas di sekolah atau kampus, dan sebagainya. Media sosial menjadi sarana bagi mereka untuk mengembangkan diri dan juga orang lain.

- Gerakan-gerakan sosial atau/dan politik. Romo Mangun menjelaskan jaringan pas-toral berupa gerakan-gerakan sosial atau dan politik dalam bentuk yang masih tradisional yakni pra teknologi 
informasi. Kini gerakan sosial dan politik tersebut kini bergerak dalam senyap. Mereka kini tidak hanya memunculkan gerakan dalam bentuk unjuk rasa, berkumpul berdiskusi di dalam ruang geografis tertentu. Kini mereka menggunakan sistem operasi terjaring. Gerakan mereka menjadi tidak lagi tampak. Kasat mata. Justru hiruk pikuk gerakan yang terlebih banyak bertujuan untuk menggalang perolehan suara ramai terjadi di dalam-jaringan. Lepas dari dampak negatifnya, hal yang patut disyukuri ialah peluang untuk membangun jejaring dalam konteks sosial dan politik menjadi demikian mudah. Itulah keberuntungan yang dimiliki oleh manusia jaman kini yang sedemikian terjaring.

- Badan-badan atau lembaga-lembaga pengabdian profesional. Para profesional di bidang kesehatan, pendidikan, sosial, politik, wartawan, dan sebagainya kini dengan mudah terjaring dalamjaringan. Mereka tidak perlu banyakbanyak berta-tap muka dalam usaha menyelesaikan masalah sesuai dengan bidang keahlian mereka. Dengan arus komunikasi dan informasi yang sedemikian gampang, proses keterlibatan dapat dilaksanakan secara lebih efisien dan efektif.

- Jaringan lobi yang kolektif maupun individual yang berbincang hati-hati di ruang privasi. Percakapan gelenakglenik ini semakin terfasilitasi lewat pembi-caraan di dalam-jaringan. Lobi kini terjalin lewat perantaraan antar gawai. Arus pertukaran informasi lebih hectic karena segenap pembicaraan berlang-sung lewat tatap gawai. Tatap muka masih penting karena butuh aksi klari-fikasi yang kerap sulit berlangsung melalui tatap gawai. Harapannya semoga percakapan dalam bentuk lobi ini dapat menghasilkan keputusan, gerakan, dan gagasan yang menginspirasi banyak pihak dalam usaha mencapai kesejahteraan umum atau bonum communae. Semoga lobi-lobi yang terjalin di dalam-jaringan bukanlah sekadar demi kepentingan individu yang individualis seperti namanya individualisme terjaring. Justru gelenak-glenik itu dapat melampaui unsur egosentris dan sektarian sehingga menjadi pribadi yang sungguh berelasi dan berbagi dengan sesamanya.

Situasi diaspora yang ada di dalam gagasan Romo Mangun kini sudah semakin terjaring (networked). Artinya kondisi terpisah-pisah dan terpecah-pecah itu memiliki ikatan tali relasi yang walaupun tipis tetapi tetap mampu merawat jalinan relasi. Bahkan tanpa tatap muka tatap fisik, relasi tetap terbangun lewat jaringan di media sosial. Terkait dengan situasi demikian, Romo Mangun secara cespleng menggambarkan sosok pastoral idaman demikian

"Jadi, gambaran kami tentang gembala (lebih tepat dalam bahasa kini task-force officer, kepala kelompok tugas, kapokgas) diaspora ialah seorang pastor (imam atau awam) yang bergerak dengan mobilitas lincah dan selalu membawa telepon genggam. Ia tidak berkantor birokratis di suatu gedung ber-AC di belakang meja jati seberat setengah ton dengan suatu set kursi empuk setebal $50 \mathrm{~cm}$ di sudut salon. Akan tetapi, ia berada dalam suatu mobil van (kombi) tahan banting yang dilengkapi dengan meja kerja, telepon, komputer data dan informasi (membonceng hubungan dengan modem/ internet keuskupan), kotak makanan minuman dan seperangkat radio-kaset, syukurlah TV dan video informatif. Jok mobil sewaktu-waktu dapat disetel menjadi tempat tidur bila perlu menginap bebas, dengan koper pakaian, alat cukur, sikat-pasta gigi, dsb., (tak perlu kosmetik mahal segala) yang praktis untuk perjalanan yang bersinambung. Dan tidak boleh lupa Alkitab, buku doa, dan kepustakaan (iptek-imtek), alat-alat Misa Kudus dan minyak suci tentu saja. Dengan membawa buku jadwal perkontakan dan agenda pertemuan yang sistematis (demi efisiensi dan penghematan bensin serta waktu), dengan sekian pribadi-pribadi dan kelompok-kelompok aktivitas titik-titik simpul jaringan diaspora di mana-mana yang perlu dan urgen dikunjungi, dipantau, diteguhkan, dikoordinasi, dan didisain strategi dan taktik-taktik operasionalnya. Lebih bagus lagi sang pastor disertai 
seseorang yang berfungsi sopir sekaligus sekretaris/asisten pribadi, ahli mesin mobil dan komputer. Tidak dikucilkan, gembala turba diaspora itu bisa saja seorang atau dua orang perempuan (why not) yang (idealnya) gesit, lincah, cerdas, pemberani, tetapi penuh keibuan dan pencinta umat Gereja, luwes pandai berkomunikasi dengan kalangan elite dan terutama dan teristimewa yang jembel. Tentu boleh saja dia mempunyai kamar kantor di keuskupan atau paroki, tetapi kantornya sebetulnya di mana-mana. Di mana ada titik simpul pastoral diaspora, di situlah kantornya (dan logis juga, motelnya) dan Gereja ibadatnya." 65

Apa yang digagas oleh Romo Mangunwijaya sudah selangkah lebih maju dan visinya ke depan. Hal-hal yang ia sebut di atas kini sudah sedemikian kompak. Semua peralatan yang dibutuhkan si kapokgas itu hanya seukuran genggaman tangan. Semuanya ada di situ. Teknologi Informasi dan Komunikasi sungguh mewujudkan sarana dan prasarana yang memungkinkan si kapokgas itu menjalankan tugasnya dengan lebih gesit dan lincah. Gambaran ini mengingatkan pada kutipan berikut, "Serigala mempunyai liang dan burung mempunyai sarang, tetapi Putra Manusia tidak mempunyai tempat untuk meletakkan kepalaNya" (Mat 8:20).

Artinya, kelekatan geografis dari Sang Gembala perlu dilepaskan. Sang Gembala atau pelayan pastoral dan juga semua saja yang mengaku diri beriman, mesti bersikap lepas dari stabilitas loci atau keterikatan pada tempat tertentu. Mereka mesti mobil (mobile) atau senantiasa bergerak. Kini dengan teknologi informasi dan komunikasi, situasi bergerak itu semakin terfasilitasi. Bahkan stabilitas loci bakal terakomodasi dengan media-media sosial. Tidak perlu lagi keluar kamar, kini sapaan, teguran, dan teguhan dapat disampaikan. Romo Mangun pun menegaskan bahwa pelayan pastoral itu mesti memiliki improvisasi yang tinggi, memiliki kepekaan perasaan yang mendalam, dan berintuisi kuat.

\section{KESIMPULAN: GEREJA TERJARING (NETWORKED CHURCH)}

Penelusuran pustaka mengenai 'makna Gereja sebagai komunio' berujung pada gagasan iman Kristiani yang relasional. Aspek komunio tidak dapat lepas dari asumsi dasar relasional bahkan dalam situasi kontekstual pengalaman beriman yang komunal dari umat di Amerika Latin. Konteks Indonesia sendiri memuat landasan relasional yang diungkapkan oleh Driyarkara dari sudut pandang filosofis terlebih Pancasila. Manusia saling terhubung karena diciptakan secitra dengan Allah yang berelasi, Allah Tritunggal. Iman Kristiani Katolik itu relasional.

Dengan memahami Gereja sebagai komunio, paguyuban dan persekutuannya mesti dikemukakan dan dihidupi terlebih dahulu baru kemudian aspek hierarki, institusi, dan yuridisnya. Teladan dari para rasul dan Gereja perdana kiranya menjadi pegangan agar nyala api komunio tetap menyala dalam iman dan hidup menggereja seperti di dalam Kisah Para Rasul (Bdk. Kis 2:42-47). Muatan misteri juga mesti diberi tempat dalam komunio agar paguyuban itu tidak semata-mata bernilai sosiologis dan kultural belaka, namun juga eklesial. Pagu-yuban tersebut sungguh menjadi tanda dan sarana kehadiran Allah di dunia. Maka dari itu, pintu Gereja mesti terbuka lebar dengan siapa pun yang berkehendak baik. Pintu Gereja tak hanya dipahami sebatas pintu fisik belaka namun juga pintu digital yang memungkinkan paguyuban umat beriman ini menyapa banyak orang. Selain itu banyak orang dapat menjang-kau dan mengakses nilai-nilai hidup dari paguyuban melalui ranah digital. Umat yang tersebar-sebar atau diaspora memiliki akses tambahan untuk mengungkapkan imannya yang relasional itu. Gereja itu memang Katolik atau umum.

Aspek relasional tidak hanya memperkaya makna Gereja sebagai komunio di dalam komunitas umat beriman Kristiani daring, narasi iman yang dibagikan dan dihayati di dalamnya mempererat ikatan relasional tersebut. Kisah hidup, terlebih pengalaman akan Allah di dalam realitas manusiawi baik itu luring dan daring menjadi kunci 
untuk menjaga komitmen antar pribadi di dalam komunitas. Bahkan, pribadi di dalam komunitas belajar dan dididik untuk memupuk kewajiban moral Kristiani lewat mendengarkan dan mengalami sendiri narasi besar iman Kristiani yang tertulis dari Perjanjian Lama dan Perjanjian Baru dan juga lewat kesaksian hidup umat beriman lainnya. Dengan berlangsungnya tukar menukar peng-alaman hidup dalam bentuk cerita yang lebih dari sekadar informasi di dalam komunitas umat beriman daring, komitmen dan kewajiban moral dapat lestari. Gereja Ter-jaring membutuhkan narasi iman sebagai bahan bakar ikatan relasional antar pribadi di dalamnya.

Dengan hadirnya dunia digital, teologi diundang untuk masuk dalam tegangan yang kreatif. Terdapat unsur paradoks baru baik itu untuk beriman dan berteologi. Tempat di mana manusia berinteraksi dan berelasi tak hanya di dunia fisik dengan batasan privat dan publik. Kini hadir pula dunia digital. Tegang-annya ada di antara fisik dan digital, daring dan luring. Batasannya pun tidak tegas. Antara dua ranah itu saling tumpang tindih, saling ulang alik. Gereja yang komunio sungguh-sungguh diundang untuk makin mutakhir, makin up to date. Untuk dapat sampai ke situ sekali lagi perlu diingat bahwa paradoksal daring dan luring mesti menyingkapkan unsur ilahi dan misteri di sana. Peran Roh Kudus sebagai Allah Penyelenggara yang hadir terus menerus dalam keseharian perlu dikenali dan disadari peran-Nya. Allah Roh Kudus itulah yang menjamin tegangan kreatif ini berlang-sung konstruktif sehingga iman yang rela-sional dan komunal tetap terselenggara di dalam sistem operasi sosial terjaring.

Dapatkah disebut Gereja yang komunio di era milenium ketiga ini sebagai Gereja Terjaring (Networked Church)? Gereja yang terjaring berarti persekutuan atau paguyuban dari pribadi per pribadi yang beriman Kris-tiani di mana konteks hidup mereka sudah sedemikian ulang-alik dan timpang tindih aktivitas dan interaksi relasionalnya baik itu di luar-jaringan mau pun di dalamjaringan. ${ }^{66}$ Gagasan Gereja Terjaring ini lebih luas dan dalam maknanya dari sekadar penghubung (hub) seperti yang disebut oleh Spadaro sebagai church as a hub. ${ }^{67}$ Bila Gereja hanya dipahami sebagai hub, maka Gereja kehi-langan makna sakramentalnya lantaran Gereja hanya menjadi sarana manusiawi belaka untuk mempertemukan umat beriman. Nuansanya justru lebih dekat dengan gagasan Gereja diasporanya Romo Mangun yang mengedepankan kombinasi pengelolaan umat beriman yang administratif teritorial sekaligus kategorial, Gereja yang piramidal sekaligus jaringan titik-titik simpul organik. ${ }^{68}$ Tentu sikap kritis terhadap Gereja Diaspora Mangunwijaya perlu dikenakan karena konteks Romo Mangun di era modern masyarakat Indonesia berbeda dengan konteks kini dengan individualisme terjaring.

Penjelajahan makna Gereja sebagai komunio memang diperkaya. Ada sesuatu yang ditambah dan berkembang dari Gereja dalam konteks jaman yang semakin terhubung dan terjaring. Sesungguhnya, teknologi yang demikian canggih itu menggali hakekat dasar manusia Kristiani yang butuh relasi, butuh berkomunikasi, butuh berkomunio. Tentu konteks demikian dipengaruhi oleh situasi jaman yang semakin hilir mudik sedemikian cepatnya sehingga banyak pribadi kesulitan menemukan ruang perjumpaan. Ada banyak pertemuan tetapi belum tentu itu menjadi ruang perjumpaan di mana sisi pribadinya sebagai manusia sungguh disapa dan menyapa yang lain. Dalam arti yang teologis, perjumpaan antar pribadi itu ialah perjumpaan dengan sesama manusia. Di dalam perjumpaan dengan yang lain itu Allah ditemukan, makna eksistensialnya dirayakan. Hadirnya dunia digital menuntut manusia untuk makin menemukan Allah yang hadir secara sakramental di dalam diri yang lain, di dalam ciptaan bahkan di dalam representasi digital dalam-jaringan. Barangkali memang kesannya perjumpaan yang diperantarai oleh teknologi itu menghadirkan nuansa alone together seperti yang diwanti-wanti oleh Turkle. Bahkan ia pun mengajak banyak orang untuk sungguhsungguh merestorasi perca-kapan sejati (reclaiming conversation) ${ }^{69}$, bukan hanya obrolan murahan yang sedemikian murahnya hingga hanya berharga untuk di-read 
saja tanpa ditanggapi (reply). Maka, makna Gereja sebagai komunio merupakan modal untuk maju dan berkembang merawat iman Kristiani yang relasional yang dalam bahasa kekinian menjadi networked atau terjaring; tak lain dan tak bukan dengan cara berbagi narasi hidup akan iman Kristiani yang eksistensial dan aktual.

\section{CATATAN AKHIR}

1 Y.B. Mangunwijaya, Gereja Diaspora (Yogyakarta: Kanisius, 1999), 212-214.

2 Rainie dan Wellman mengatakan "Kami menyebut buku ini Networked: The New Social Operating System, untuk menegaskan bagaimana jaringanjaringan di antara manusia telah mentransformasi bagaimana kita berhubungan baik secara personal dan elektronik." Lee Rainie and Barry Wellman, Networked: The New Social Operating System (London: MIT Press, 2012), ix, 6-7.

3 Penulis-penulis lain mencoba menjelaskan mengenai Katolisisme dengan pendekatan berbeda. Pada dasarnya penulis-penulis tersebut mengemukakan bahwa Katolisisme merupakan suatu tradisi Kristiani. Lih. Gerald J O'Collins and Mario J Farrugia, Catholicism: The Story of Catholic Christianity (Oxford: Oxford University Press, 2003). Gerald J O'Collins, Catholicism: A Very Short Introduction, A Very Short Introduction, vol. 13 (Oxford: Oxford University Press, 2008). James Buckley, Frederick Christian Bauerschmidt, and Trent Pomplun, The Blackwell Companion to Catholicism, Blackwell Companions to Religion, vol. 10 (Oxford: Blackwell Publishing, 2007). Henri de Lubac, Catholicism: A Study of Dogma in Relation to the Corporate Destiny of Mankind, trans., Lancelot C. Sheppard (London: Burns and Oates, 1950).

4 Richard P McBrien, Catholicism: New Study Edition--Completely Revised and Updated (San Francisco: Harper Collins, 2013), 16-17.

5 McBrien, Catholicism: New Study Edition-Completely Revised and Updated, 12.

6 McBrien, Catholicism: New Study Edition-Completely Revised and Updated, 13.

7 McBrien, Catholicism: New Study Edition-Completely Revised and Updated, 570.

8 Ide Tom Jacobs persekutuan karena partisipasi sesungguhnya berangkat dari elaborasinya akan 'koinonia' dalam eklesiologi Paulus. Komunio merupakan kata Latin untuk mengalihbahasakan koinonia, kata bahasa Yunani. Lepas dari perdebatan mengenai makna literer dan kontekstual yang rupanya cukup berbeda dari komunio dan koinonia, penulis mengambil perhatian makna keduanya sebagai 'persekutuan karena partisipasi'. Lih. Tom Jacobs, "Koinonia Sebagai Kunci Eklesiologi Paulus," Orientasi Baru 2, (1988).; dan Encyclopedia of Christian
The church as a network of people and resources and building sustainable relational links between people both inside and outside their particular communities of faith.

(Dwight Friesen, Thy Kingdom Connected $)^{70}$

Theology: 3 Volume Set (New York: Routledge, 2005), s.v. "Communion."

9 John D. Zizioulas, Being as Communion: Studies in Personhood and the Church, ed. Christos Yannaras and Costa Carras, Contemporary Greek Theologians Series (New York: St. Vladimir's Seminary Press, 1985), 21.

10 Komunio terkait dengan persahabatan akan dibahas secara singkat. Lih. Todd Salzman, "Communion Ecclesiology: Friendship as a Model for Communication within the Church," Chicago Studies 41, no. 3 (2002)

11 Dennis M. Doyle, "Möhler, Schleiermacher, and the Roots of Communion Ecclesiology," Theological Studies 57, no. 3 (1996): 472.; dan Dennis M. Doyle, Communion Ecclesiology: Vision and Versions (New York: Orbis Books, 2000), 2528

12 Doyle, Communion Ecclesiology: Vision and Versions, 13.

13 Dennis M Doyle, "Henri De Lubac and the Roots of Communion Ecclesiology," Theological Studies 60, no. 2 (1999).

14 Henri de Lubac, The Church: Paradox and Mystery, trans., James R. Dunne (New York: Alba House, 1969), 14

15 "the simultaneity of the one and the other. ... They do not sin against logic, whose laws remain inviolable; but they escape its domain. They are the for fed by the against, the against going so far as to identify itself with the for; each one of them moving into the other without letting itself be abolished by it and continuing to oppose the other, but so as to give it vigor." Henri de Lubac, Paradoxes of Faith, trans., Sadie Kreilkamp and Paule Simon (San Fransisco: Ignatius Press, 1987), 12.

16 "We can participate in a mystery, but its ultimate depths go far beyond us. We can experience a mystery intimately, but its final comprehension transcends our powers of understanding. A paradox is something that, while it may incline one toward mystery, is itself more mundane. A paradox results from the coexistence in relational tension of two or more things that appear on the surface to be contradictory or opposite." Doyle, "Henri De Lubac and the Roots of Communion Ecclesiology," 212.

17 Doyle, "Henri De Lubac and the Roots of Communion Ecclesiology," 218-226. 
18 Dennis Doyle menyebut kelimanya sebagai five touchstones of the visions, Doyle, Communion Ecclesiology: Vision and Versions, 175-178.

19 Avery Dulles, Models of the Church, 2 ed. (New York: Gill and Macmillan, 1988), 1-3.

20 Karl Rahner menyebut demikian, "The "economic" Trinity is the "immanent" Trinity and the "immanent" Trinity is the "economic" Trinity". Karl Rahner, The Trinity, trans., Joseph Donceel (New York: Herder and Herder, 1970).

21 Miroslav Volf mengungkapkan demikian, "Zizoulas's communio-ecclesiology is based on an ontology of person acquired from a consideration of the nature of the triune God. This ontology in its own turn is conceived in constrast to any individualism destructive to community (and thus to life itself) as well as to any monistic, isolated ontology that necessarily excludes freedom and in which for that very reason personhood must lack any "ontological content”. Miroslav Volf, After Our Likeness: The Church as the Image of the Trinity (Cambridge: William B. Eerdmans Publishing, 1998), 75-76.

22 "The being of God is a relational being: without the concept of communion it would not be possible to speak of the being of God. ... It would be unthinkable to speak of the "one God" before speaking of the God who is 'communion,' that is to say, of the Holy Trinity. The Holy Trinity is a primordial ontological concept and not a notion which is added to the divine substance ... The substance of God, "God", has no ontological content, no true being, apart from communion." Zizioulas, Being as Communion: Studies in Personhood and the Church, 17.

23 Zizioulas, Being as Communion: Studies in Personhood and the Church, 17.

24 Campbell dan Garner menjelaskan tiga poin bila manusia dipandang sebagai imago Dei yakni pertama, gambar dan rupa Allah itu secara intrinsik inheren di dalam substansi manusia sehingga memampukannya untuk berelasi, kedua, gambaran tersebut memiliki aspek relasional yang memungkinkan atau hadir di dalam relasi Allah dan manusia, ketiga, bila gambar tersebut bekerja maka manusia menghadirkan Allah di dunia sebagai agen-Nya. Jadi terdapat relasi dan interaksi antara Allah dengan manusia, manusia dengan manusia, dan manusia dengan ciptaan lainnya. "to be human is to be declared so by God, to be connected to relationship with God, and to be involved in loving agency in the world, wherever they might be." Heidi A Campbell and Stephen Garner, Networked Theology: Negotiating Faith in Digital Culture, ed. William A. Dyrness and Robert K. Johnston, Engaging Culture (Grand Rapids: Baker Academic, 2016), 132.

25 Elizabeth Teresa Groppe, "The Contribution of Yves Congar's Theology of the Holy Spirit," Theological Studies 62, no. 3 (2001).; dan Elizabeth Teresa Groppe, Yves Congar's Theology of the Holy Spirit, ed. Kimberly Rae Connor, American Academy of Religion Academy Series (Oxford: Oxford University Press, 2004).
26 "The divine persons exist with, through, and for one another. Human persons made in the imago Dei exist likewise in a "being-toward" (être-á) one another and find fulfillment only in communion. We are destined to go beyond self in knowledge and love of another; most foundationally, we have an "in-built capacity to being called by God" Groppe, "The Contribution of Yves Congar's Theology of the Holy Spirit," 457-458.

27 "Human freedom is not simply an individual freedom of choice but rather freedom for true relationships of mutuality and communion, relationships of active invitation to others and active receptivity to God" Groppe, "The Contribution of Yves Congar's Theology of the Holy Spirit," 458.

28 Thomas Sheehan, "Rahner's Transcendental Project," in The Cambridge Companion to Karl Rahner, ed. Declan Marmion and Mary E Hines(New York: Cambridge University Press, 2005)

29 "To judge by its operations, therefore, human being is an otheredness that is always self-related, and a self-relatedness that cannot exist without being othered. Since relation-to-another is the only way humans can relate to themselves, we may define human being as self-related otheredness." Sheehan, "Rahner's Transcendental Project," 3031.

30 Sheehan, "Rahner's Transcendental Project," 31.

31 Sheehan, "Rahner's Transcendental Project," 32.

32 Roberto S. Goizueta, Caminemos Con Jesús: Toward a Hispanic/Latino Theology of Accompaniment (New York: Orbis Books, 1995), 47-76.

33 "My identity is given me by my parents, relatives, friends, and many other relationships and communities; there is no "I" without all these others. I am a particular, concrete, and unique embodiment of all those relationships; when someone encounters me, they also encounters my parents, relatives, friends, community, my people, as well as the God who created me and the earth which nourishes me." Goizueta, Caminemos Con Jesús: Toward a Hispanic/Latino Theology of Accompaniment, 50.

34 Nicolaus Driyarkara, Karya Lengkap Driyarkara: Esai-Esai Filsafat Pemikir Yang Terlibat Penuh Dalam Perjuangan Bangsanya, ed. A Sudiarja et al. (Jakarta: Gramedia Pustaka Utama, 2006), 655.

35 Dennis Doyle membandingkan eklesiologi Charles Journet dan Yves Congar. Terkait relasi antara Gereja dengan dunia, Journet memisahkannya sedangkan Congar memadupadankannya. Lih. Doyle, Communion Ecclesiology: Vision and Versions, 48; Dennis M. Doyle, "Journet, Congar, and the Roots of Communion Ecclesiology," Theological Studies 58, no. 3 (1997).

36 Doyle, Communion Ecclesiology: Vision and Versions, 48.

37 Charles Journet dan Yves Congar sama-sama menekankan peran Roh Kudus dan Yesus Kristus di dalam Gereja. Namun Journet memahami peran Roh Kudus dan Kristus sama dalam pembentukan awal Gereja sedangkan Congar melihatnya 
berbeda. Lih. Doyle, "Journet, Congar, and the Roots of Communion Ecclesiology," 472-473

38 "By pneumatology I mean something other than a simple dogmatic theology of the third Person. I also mean something more than, and in this sense different from, a profound analysis of the indwelling of the Holy Spirit in individual souls and his sanctifying activity there. Pneumatology should, I believe, describe the impact, in the context of a vision of the Church, of the fact that the Spirit distributes his gifts as he wills and in this way builds up the Church." Lih. Groppe, "The Contribution of Yves Congar's Theology of the Holy Spirit," 460.; seperti dikutip dari Yves Congar, I Believe in the Holy Spirit, trans., David Smith (New York: Seabury, 1983), 1.156.

39 Penyebab (cause dalam Bahasa Inggris, aition atau aitia dalam Bahasa Yunani) digunakan untuk menjelaskan mengenai penyebab dari sesuatu dengan menjawab empat pertanyaan: [1] apa bahan dasarnya? (penyebab material atau material cause); [2] apa yang membuatnya menjadi ada? (penyebab efisien atau efficient cause); [3] apakah sesuatu itu? (penyebab formal atau formal cause); dan [4] apa gunanya atau tujuannya? (penyebab final atau final cause) David Furley, Routledge History of Philosophy Volume 2: Aristotle to Augustine (New York: Taylor \& Francis, 1999), 430. Dengan menggunakan empat penyebab Aristotelian, Thomas Aquinas memaparkan definisi Gereja. Penyebab formal Gereja ialah hierarki; penyebab materialnya ialah awam; penyebab efisien ialah Trinitas (tidak langsung) dan Kristus (langsung); dan penyebab final ialah visiun beatifika. Dari penjelasan ini tampak bahwa Gereja merupakan suatu organisasi formal hierarkis. Penentu utama Gereja ialah kaum hierarki yang mempunyai wewenang tertentu, yang salah satunya ialah peran yuridis, bagi anggota Gereja. Lih. Doyle, "Journet, Congar, and the Roots of Communion Ecclesiology," 466.

40 Yves Congar, The Mystery of the Church, trans., A. V. Littledale (Baltimore: Helicon, 1969).

41 "This ecclesiology emphasizes that it is the Holy Spirit who together with Jesus Christ co-institutes the Church, empowers the Church's sacraments and doxology, builds up the Church with charisms, and makes the Church one, holy, catholic, and apostolic." Groppe, "The Contribution of Yves Congar's Theology of the Holy Spirit," 461.

42 Doyle, Communion Ecclesiology: Vision and Versions, 51

43 Groppe, "The Contribution of Yves Congar's Theology of the Holy Spirit," 462.

44 "In effect, every active movement within the church represents a movement beyond what went before it and takes its force from a new inquiry into the sources and the enduring energies of the church's life. In that way, every active movement has a certain quality of reform. This is as true of the contemporary period as of any other, perhaps even truer today." Yves Congar, True and False Reform in the Church, trans., Paul Philibert (Minnesota: Liturgical Press, 2010), 25.
45 Congar, True and False Reform in the Church.

46 Congar, True and False Reform in the Church, 102.

47 "The leaders of the people - kings and priests - are themselves sinners. Only the word and the fidelity of God do not fail." Congar, True and False Reform in the Church, 57.

48 "Sometimes God seizes upon a man and makes him a prophet, someone to speak for God, who speaks a word from God and thus becomes, in the midst of a faithless people, a sort of link to God. Israel really continues to exist only through these interventions from God." Congar, True and False Reform in the Church, 57.

49 "Our character is constituted by the rules, metaphors, and stories that are combined to give a design or unity to the variety of things we must and must not do in our lives. If our lives are to be reflective and coherent our vision must be ordered around dominant metaphors or stories. Therefore it is crucial to our moral life to allow the metaphors that make up our vision to check and balance each other in terms of their appropriateness for the various demands of our life and the overall "life plan" that we live." John Berkman and Michael Cartwright, eds., The Hauerwas Reader (Durham and London: Duke University Press, 2001), 169.

50 Stanley Hauerwas, A Community of Character: Toward a Constructive Christian Social Ethic (London: University of Notre Dame Press, 1981), 10-11.

51 Heidi A. Campbell, Exploring Religious Community Online: We Are One in the Network, ed. Steve Jones, Digital Formations, vol. 24 (New York: Peter Lang, 2005), 39.

52 "... the church ... by the conjunction of the two uniting the divine formal principle with the human material principle. In this sense, the church is the divine-human reality that is born of this union." Congar, True and False Reform in the Church, 70.

53 Terkait dengan definisi networked theology, Campbell dan Garner menjelaskan bahwa "By definition, a networked theology is inherently relational, with the network motif expressly describing various relationships within the network, and so we would expect to see manifested in it elements of this Trinitarian relationality, together with understandings of community found in descriptions of the church, family, and neighborhood." Campbell and Garner, Networked Theology: Negotiating Faith in Digital Culture, 124.

54 “... is flesh-and-blood presence, seen in the incarnation of God in Jesus of Nazareth and physical church communities, a nonnegotiable in true Christian community? Are the notions of church limited to a completely physical representation in a particular time and space? Can one be truly human in an online environment and how does one manifest love in that kind of environment?" Campbell and Garner, Networked Theology: Negotiating Faith in Digital Culture, 125.

55 "Theologically, our humanity and community are sourced in God, and that remains the case whether in physical or digital environments. To be human 
is to be called to bear the image and likeness of God, who is, in essence, the Trinitarian community of love, and then be called to bear that image in love of God and love of neighbor. The recognition of others as image bearers, as persons rather than things, and as neighbors is intimately connected with forming true community, which transcends purely physical environments. Thus, image bearing and being human are tied to agency in the world, whether digital or physical, reflecting the reality that those we encounter online are as much our neighbors as those over the backyard fence." Campbell and Garner, Networked Theology: Negotiating Faith in Digital Culture, 132.

56 Antonio Spadaro, Cybertheology: Thinking Christianity in the Era of the Internet (New York: Fordham University Press, 2014), 33-35.; dan Campbell and Garner, Networked Theology: Negotiating Faith in Digital Culture, 132-139.

57 Terkait dengan tiga dimensi ini Campbell dan Garner mengelaborasi gagasannya dengan berangkat dari ide Simon Carey Holt dalam Simon Carey Holt, God Next Door: Spirituality and Mission in the Neighbourhood (Brunswick East, Australia: Acorn Press, 2007).

58 Rainie and Wellman, Networked: The New Social Operating System, 95-96.

59 "Therefore, part of the answer to the question of where is my neighbor is intrinsically linked to our understanding and perception of boundaries - not only where we see those boundaries existing but also how those boundaries came into existence, who those boundaries affect, and what happens when those boundaries are crossed." Campbell and Garner, Networked Theology: Negotiating Faith in Digital Culture, 135.

60 "... we will have to acknowledge that our theological reflection, both on our lives and generated by our lives and generated by our lives, will need to take digital "places" into account." Campbell and Garner, Networked Theology: Negotiating Faith in Digital Culture, 137.

61 "Therefore, if our world now includes new nonphysical places and representations of human life, we should not be surprised to find God, who is Lord of all, present in our digital spaces and our human encounters there." Campbell and Garner, Networked Theology: Negotiating Faith in Digital Culture, 138.

62 "The third dimension extends the notion of neighborhood to include ethical and communal aspects of how the people of God, the followers of Jesus Christ, live out their lives faithfully in those everyday worlds. ... If we exists in both physical and digital worlds, which often overlap in interesting and novel ways, the neighborhood in which we are embedded spans those worlds too." Campbell and Garner, Networked Theology: Negotiating Faith in Digital Culture, 139.

63 Gagasan mengenai situasi dunia yang cair dibahas oleh Zygmunt Bauman dalam Zygmunt Bauman, Liquid Modernity (Cambridge: Polity Press, 2013).
64 Mangunwijaya, Gereja Diaspora, 131-137.

65 Mangunwijaya, Gereja Diaspora, 140-141.

66 Heidi Campbell menemukan dalam penelitian kualitatifnya terhadap tiga komunitas daring bahwa komunitas daring itu melengkapi, menambah, dan memperkaya komunitas luring. Bahkan ia menemukan ciri-ciri komunitas daring yang selaras dan memperkaya komunitas luring yakni relasi, perhatian, dihargai, hubungan/ koneksi, komunikasi akrab, dan berbagi iman. “...enam ciri yang dikehendaki seseorang akan komunitas, berda-sarkan observasi studi ini. Manusia mencari relasi untuk terhubung dan berkomitmen dengan yang lain. Mereka berhasrat untuk memperhatikan dan diperhatikan oleh komunitasnya. Mereka mengha-sratkan untuk dihargai, dipandang bernilai sebagai individu dan bagian dari komunitas. Mereka mengejar komunikasi yang konsisten dengan anggota komunitasnya. Mereka mengusahakan komunikasi yang intim, di mana tiap individu secara terbuka membagikan hidup iman dan spiritualnya. Akhirnya, mereka berkumpul karena berbagi iman yang sama sehingga mempengaruhi bagaimana mereka melihat yang lain di dalam-jaringan dan bagaimana mereka memahami interkoneksi aspekaspek kehidupan di dalam-jaringan dan luarjaringan. Hal ini menghadirkan gambaran komunitas berbasis pada komunikasi, kesamaan, kerja sama, komitmen, dan perhatian. Hal itu mempotret komunitas yang lebih perhatian pada bagaimana tiap individu diperlakukan dari pada struktur atau fokus pada komunitas. Campbell, Exploring Religious Community Online: We Are One in the Network, 187.

67 Spadaro, Cybertheology: Thinking Christianity in the Era of the Internet, 37-40.

68 "Hal-hal penting dalam sistem jaringan seperti itu ialah elemen komunikasi akrab informal, suasana kekeluargaan, keguyuban, susunan kerja sama yang melewati jalan lorong yang teratur, tetapi dengan multi-connection yang luwes, mampu mengatasi berbagai persoalan relevan dan aktual tanpa terhambat oleh birokrasi seperti dalam Gereja piramida. Gereja jaringan itu Bhinneka, namun terkoordinasi tunggal, yang saling berdialog, baik top down, dari atas ke bawah maupun buttom up, dari bawah ke atas. Ia bahkan sebenarnya tanpa hubungan yang didominasi status atas-bawah; atau lebih tepat, dalam bahasa sekarang, suatu bentuk kinergi atau kinerja yang saling melengkapi dan mendewasakan; mandiri, tetapi tidak liar menjadi sekte-sekte yang serba sempal." Mangunwijaya, Gereja Diaspora, 97.

69 Sherry Turkle, Reclaiming Conversation: The Power of Talk in a Digital Age (New York: Penguin Press HC, 2015).

70 Dwight J Friesen, Thy Kingdom Connected: What the Church Can Learn from Facebook, the Internet, and Other Networks (Grand Rapids: Baker Books, 2009), 112-117. 


\section{DAFTAR RUJUKAN}

Bauman, Zygmunt. Liquid Modernity. Cambridge: Polity Press, 2013.

Berkman, John and Michael Cartwright, eds. The Hauerwas Reader. Durham and London: Duke University Press, 2001.

Buckley, James, Frederick Christian Bauerschmidt and Trent Pomplun. The Blackwell Companion to Catholicism. Vol. 10 Blackwell Companions to Religion. Oxford: Blackwell Publishing, 2007.

Campbell, Heidi A and Stephen Garner. Networked Theology: Negotiating Faith in Digital Culture Engaging Culture, Edited by William A. Dyrness and Robert K. Johnston. Grand Rapids: Baker Academic, 2016.

Exploring Religious Community Online: We Are One in the Network. Vol. 24 Digital Formations, Edited by Steve Jones. New York: Peter Lang, 2005.

Congar, Yves. The Mystery of the Church. Translated by A. V. Littledale. Baltimore: Helicon, 1969.

I Believe in the Holy Spirit. Translated by David Smith. New York: Seabury, 1983.

True and False Reform in the Church. Translated by Paul Philibert. Minnesota: Liturgical Press, 2010.

de Lubac, Henri. Catholicism: A Study of Dogma in Relation to the Corporate Destiny of Mankind. Translated by Lancelot C. Sheppard. London: Burns and Oates, 1950.

The Church: Paradox and Mystery. Translated by James R. Dunne. New York: Alba House, 1969.
Paradoxes of Faith. Translated by Sadie Kreilkamp and Paule Simon. San Fransisco: Ignatius Press, 1987.

Doyle, Dennis M. "Henri De Lubac and the Roots of Communion Ecclesiology." Theological Studies 60, no. 2 (1999): 209-227.

"Möhler, Schleiermacher, and the Roots of Communion Ecclesiology." Theological Studies 57, no. 3 (1996): 467-480.

"Journet, Congar, and the Roots of Communion Ecclesiology." Theological Studies 58, no. 3 (1997): 461-479.

Communion Ecclesiology: Vision and Versions. New York: Orbis Books, 2000.

Driyarkara, Nicolaus. Karya Lengkap Driyarkara: Esai-Esai Filsafat Pemikir Yang Terlibat Penuh Dalam Perjuangan Bangsanya, Edited by A Sudiarja, G. Budi Subanar, St. Sunardi and $\mathrm{T}$ Sarkim. Jakarta: Gramedia Pustaka Utama, 2006.

Dulles, Avery. Models of the Church. 2 ed. New York: Gill and Macmillan, 1988.

Friesen, Dwight J. Thy Kingdom Connected: What the Church Can Learn from Facebook, the Internet, and Other Networks. Grand Rapids: Baker Books, 2009.

Furley, David. Routledge History of Philosophy Volume 2: Aristotle to Augustine. New York: Taylor \& Francis, 1999.

Goizueta, Roberto S. Caminemos Con Jesús: Toward a Hispanic/Latino Theology of Accompaniment. New York: Orbis Books, 1995. 
Groppe, Elizabeth Teresa. "The Contribution of Yves Congar's Theology of the Holy Spirit." Theological Studies 62, no. 3 (2001): 451-478.

Yves Congar's Theology of the Holy Spirit American Academy of Religion Academy Series, Edited by Kimberly Rae Connor. Oxford: Oxford University Press, 2004.

Hauerwas, Stanley. A Community of Character: Toward a Constructive Christian Social Ethic. London: University of Notre Dame Press, 1981.

Holt, Simon Carey. God Next Door: Spirituality and Mission in the Neighbourhood. Brunswick East, Australia: Acorn Press, 2007.

Jacobs, Tom. "Koinonia Sebagai Kunci Eklesiologi Paulus." Orientasi Baru 2, (1988): 39-77.

Mangunwijaya, Y.B. Gereja Diaspora. Yogyakarta: Kanisius, 1999.

McBrien, Richard P. Catholicism: New Study Edition--Completely Revised and Updated. San Francisco: Harper Collins, 2013.

O'Collins, Gerald J. Catholicism: A Very Short Introduction. Vol. 13 A Very Short Introduction. Oxford: Oxford University Press, 2008.

O'Collins, Gerald J and Mario J Farrugia. Catholicism: The Story of Catholic Christianity. Oxford: Oxford University Press, 2003.
Rahner, Karl. The Trinity. Translated by Joseph Donceel. New York: Herder and Herder, 1970.

Rainie, Lee and Barry Wellman. Networked: The New Social Operating System. London: MIT Press, 2012.

Salzman, Todd. "Communion Ecclesiology: Friendship as a Model for Communication within the Church." Chicago Studies 41, no. 3 (2002).

Sheehan, Thomas. "Rahner's Transcendental Project." In The Cambridge Companion to Karl Rahner, edited by Declan Marmion and Mary E Hines, 29-42. New York: Cambridge University Press, 2005.

Spadaro, Antonio. Cybertheology: Thinking Christianity in the Era of the Internet. New York: Fordham University Press, 2014.

Tillard, Jean-Marie, Encyclopedia of Christian Theology: 3 Volume Set. New York:Routledge, 2005.

Turkle, Sherry. Reclaiming Conversation: The Power of Talk in a Digital Age. New York: Penguin Press HC, 2015.

Volf, Miroslav. After Our Likeness: The Church as the Image of the Trinity. Cambridge: William B. Eerdmans Publishing, 1998.

Zizioulas, John D. Being as Communion: Studies in Personhood and the Church Contemporary Greek Theologians Series, Edited by Christos Yannaras and Costa Carras. New York: St. Vladimir's Seminary Press, 1985. 
